\title{
Effects of Root-Zone Temperature on Photosynthesis, Productivity and Nutritional Quality of Aeroponically Grown Salad Rocket (Eruca sativa) Vegetable
}

\author{
Jie He* Xin Er See, Lin Qin, Tsui Wei Choong \\ Natural Sciences and Science Education Academic Group, National Institute of Education, Nanyang Technological University, Singapore \\ Email: *jie.he@nie.edu.sg
}

How to cite this paper: He, J., See, X.E., Qin, L. and Choong, T.W. (2016) Effects of Root-Zone Temperature on Photosynthesis, Productivity and Nutritional Quality of Aeroponically Grown Salad Rocket (Eruca sativa) Vegetable. American Journal of Plant Sciences, 7, 1993-2005.

http://dx.doi.org/10.4236/ajps.2016.714181

Received: September 11, 2016

Accepted: October 14, 2016

Published: October 17, 2016

Copyright (c) 2016 by authors and Scientific Research Publishing Inc. This work is licensed under the Creative Commons Attribution International License (CC BY 4.0).

http://creativecommons.org/licenses/by/4.0/

(c) (i) Open Access

\begin{abstract}
Although tropical high ambient temperature and humidity severely reduced the productivity of temperate plants, temperate vegetable crops such as lettuce have been successfully grown in Singapore by only cooling its root-zone. In this paper, a cool Meditteranean vegetable, Eruca sativa, was studied to understand how different RZTs can impact its shoot productivity, photosynthesis and nutritional quality. All plants were cultivated using aeroponic systems in a tropical greenhouse under hot ambient conditions where roots were subjected to four different root-zone temperatures (RZTs) of $20^{\circ} \mathrm{C}$-RZT, $25^{\circ} \mathrm{C}$-RZT, $30^{\circ} \mathrm{C}$-RZT and fluctuating ambient temperatures ranged from $25^{\circ} \mathrm{C}$ to $38^{\circ} \mathrm{C}\left[25^{\circ} \mathrm{C} / 38^{\circ} \mathrm{C}\right.$ (ambient)]-RZT. Parameters studied include shoot fresh weight (FW), photosynthetic gas exchange, midday chlorophyll (Chl) fluorescence $\mathrm{F}_{\mathrm{v}} / \mathrm{F}_{\mathrm{m}}$ ratio, Chl fluorescence photochemical quenching (qP), non-photochemical quenching ( $\mathrm{qN}$ ) and electron transport rate (ETR), total phenolic compounds and mineral content such as potassium $(\mathrm{K})$, calcium $(\mathrm{Ca})$, magnesium $(\mathrm{Mg})$ and iron $(\mathrm{Fe})$. Among the 4 different RZT treatments, E. sativa plants grown under ambient-RZT $\left(25 / 38^{\circ} \mathrm{C}-\mathrm{RZT}\right)$ had the lowest shoot and root FW while those plants grown under $20^{\circ} \mathrm{C}$-RZT had highest productivity of shoot and root. However, there were no significant differences in shoot and root $\mathrm{FW}$ in plants grown at $25^{\circ} \mathrm{C}$ and $30^{\circ} \mathrm{C}$-RZT. Compared to plants grown under $25^{\circ} \mathrm{C} / 38^{\circ} \mathrm{C}$ (ambient-RZT), lightsaturated photosynthetic $\mathrm{CO}_{2}$ assimilation rate $\left(A_{\text {sat }}\right)$ and stomatal conductance $\left(g_{\text {ssat }}\right)$ were similarly higher in $20^{\circ} \mathrm{C}-, 25^{\circ} \mathrm{C}$ - and $30^{\circ} \mathrm{C}$-RZT. All plants had midday Chl fluorescence $\mathrm{F}_{\mathrm{v}} / \mathrm{F}_{\mathrm{m}}$ ratio lower than $<0.8$ ranged from 0.785 to 0.606 with the highest and lowest ratios recorded in $20^{\circ} \mathrm{C}$-RZT and ambient-RZT plants, respectively. These results indicate that cooling the RZ of $E$. sativa plants protected their PS II from photoinactivation during midday in the greenhouse. There were no significant dif-
\end{abstract}


ferences observed in photochemical quenching (qP), non-photochemical quenching $(\mathrm{qN})$ and electron transport rate among plants grown under $20^{\circ} \mathrm{C}-, 25^{\circ} \mathrm{C}$ - and $30^{\circ} \mathrm{C}$-RZT. However, plants grown under ambient-RZT had lower $\mathrm{qP}, \mathrm{qN}$ and ETR compared to all other plants. E. sativa at $20^{\circ} \mathrm{C}-\mathrm{RZT}$ with the best developed roots had the highest dietary mineral $(\mathrm{K}, \mathrm{Mg}, \mathrm{Ca}$ and $\mathrm{Fe})$ contents but lower total phenolics content. In contrast, ambient-RZT, plants with poorly developed roots had the lowest mineral content but highest total phenolic content. The results of this study suggest that cooling of roots is a feasible method for the cultivation of E. sativa in the tropic, which enhances the content of dietary minerals in shoots.

\section{Keywords}

Chlorophyll Fluorescence, Dietary Minerals, Root-Zone Temperature, Phenolic Compounds, Photosynthetic $\mathrm{CO}_{2}$ Assimilation Rate, Stomatal Conductance

\section{Introduction}

A leafy vegetable characterized by its strong distinctive flavours, Eruca sativa, commonly known as rocket, is well known for their antioxidant and medicinal properties. As such, they are widely consumed by people or researched as alternative medications to synthetic drugs [1]-[3]. However, E. sativa are mediterranean plants which require cool temperatures for optimum growth and development. Dolezalova et al. [4] reported that $E$. sativa is best grown at temperatures from $10^{\circ} \mathrm{C}$ to $25^{\circ} \mathrm{C}$. In contrast, temperatures in the tropical greenhouse can fluctuate from $26^{\circ} \mathrm{C}$ to $38^{\circ} \mathrm{C}$. Temperate crops are vulnerable to heat stress when grown under these temperatures due to the poor root development and mineral deficiency [5]-[9] and limitation of photosynthesis [10]-[15]. Other effects of heat-stress were scorching of shoots, abscission and senescence of leaves, growth inhibition and decreased plant productivity [10] [11] [16].

A study on Brassica albogabra also showed detrimental effects of high temperatures on root morphology, such as total root length and mineral nutrition [9]. Berry (1975) studied on Atriplex glabriuscula, a cool marine climate plant, and found that photosynthetic capabilities decrease as a trade-off to adapt to higher temperatures [15]. He et al. reported that temperate crops grown in a tropical greenhouse exhibited both stomatal and non-stomatal limitation of photosynthesis [12]. Thus, a Mediterranean plant such as E. sativa is not suitable for cultivation in Singapore under natural conditions due to the negative impacts of high tropical temperature on its growth and photosynthesis. However, the cultivation of E. sativa in Singapore is possible through the use of aeroponic systems by cooling the root zone. We have previously reported that subtropical and temperate vegetable crops could be grown in the tropics with the cooling of root zones, even though aerial parts were exposed to ambient tropical temperatures [14]. Our previous results showed that cooling of RZ reduced depression of photosynthesis during periods of bright sunlight, mitigated stomatal limitations on photosynthesis due to water deficit and alleviated non-stomatal limitation resulting from 
protecting leaves from photo inactivation, and improved overall plant growth and development [12] [13].

This study aimed to invest if photosynthetic capabilities, productivity and nutritional qualities of $E$. sativa were affected under tropical conditions with different RZTs, namely at $20^{\circ} \mathrm{C}$-, $25^{\circ} \mathrm{C}$-, $30^{\circ} \mathrm{C}$ - and $25^{\circ} \mathrm{C} / 38^{\circ} \mathrm{C}$ (ambient)-RZT. Fresh weights (FW) of root and shoot were measured to determine productivity of plant at harvest. Lightsaturated photosynthetic $\mathrm{CO}_{2}$ assimilation rate $\left(A_{s a t}\right)$, stomatal conductance $\left(g_{s}\right.$ sat $)$ and midday chlorophyll (Chl) fluorescence $\mathrm{F}_{\mathrm{v}} / \mathrm{F}_{\mathrm{m}}$ ratio were measured in the greenhouse to investigate the effects of RZT on stomatal and non-stomatal limitations of photosynthesis [12]. Light response curves of photochemical quenching and non-photochemical quenching were determined to study the impacts of RZT on photosynthetic utilization of radiant energy [13]. Effects of RZT on nutritional qualities were also analysed by the comparison of total phenolic compounds and various minerals such as $\mathrm{K}, \mathrm{Ca}, \mathrm{Mg}$ and Fe.

\section{Materials and Methods}

\subsection{Plant Material and Cultural Methods}

E. sativa seeds were germinated on moist Whatman filter papers in petri dishes under laboratory conditions. Three days after germination, the seedlings were inserted into polyurethane cubes soaked in water for adaptation. After nine days of adaptation, these seedlings were transplanted into four aeroponic troughs of different temperatures. To maintain the different RZTs, all troughs were insulated using aluminum-laminated polyethylene sheets. Three water tanks were regulated using chillers to maintain the different constant RZTs at $20.1^{\circ} \mathrm{C} \pm 0.1^{\circ} \mathrm{C}, 25.0^{\circ} \mathrm{C} \pm 0.1^{\circ} \mathrm{C}, 29.6^{\circ} \mathrm{C} \pm 0.1^{\circ} \mathrm{C}$ while one of them was kept at ambient temperature range from $25^{\circ} \mathrm{C}$ to $38^{\circ} \mathrm{C}$. Full nutrient solution was supplied by misting roots at a frequency of 30 seconds at every three min. The electrical conductivity and $\mathrm{pH}$ of nutrient solutions were maintained at $2.0 \pm 0.2 \mathrm{mS}$ and $\mathrm{pH} 6.5 \pm 0.5$ respectively. The aerial parts of the plants were subjected to prevailing greenhouse conditions, where temperatures fluctuate from $25^{\circ} \mathrm{C}$ to $38^{\circ} \mathrm{C}$ and maximal photosynthetic photon flux density (PPFD) was about $600 \mu \mathrm{mol}$ photon $\mathrm{m}^{-2} \cdot \mathrm{s}^{-1}$.

\subsection{Measurements of Shoot and Root FW}

Four weeks after transplant, random plants from each treatments were harvested at $0700 \mathrm{~h}$. Shoot and roots were separated for FW measurement. The roots of each plant were washed and dabbed dry before weighing.

\subsection{Measurements of $A_{\text {sat }}$ and $g_{s ~ s a t}$}

Three weeks after transplanting, readings were taken between $0900 \mathrm{~h}$ to $1100 \mathrm{~h}$ in the greenhouse with an open infrared gas analysis system with a $6 \mathrm{~cm}^{2}$ chamber (LI-6400, Biosciences, US). Readings were taken with a LED light source, which supplied 1000 $\mu \mathrm{mol} \cdot \mathrm{m}^{-2} \cdot \mathrm{s}^{-1}$ of PPFD. The light source emitted in the wavelength ranged between 420 to $510 \mathrm{~nm}$ and $610 \mathrm{~nm}$ to $730 \mathrm{~nm}$. The spectral output of the light source has one peak 
centred at about $465 \mathrm{~nm}$ and second peak centred at about $670 \mathrm{~nm}$. Average ambient $\left[\mathrm{CO}_{2}\right]$ and relative humidity in the chamber were $400 \pm 3.5 \mu \mathrm{mol} \cdot \mathrm{mol}^{-1}$ and $70 \%$ respectively. Measurements were recorded when both $A_{\text {sat }}$ and $g_{s \text { sat }}$ were stable.

\subsection{Measurement of Midday Chl Fluorescence $F_{v} / F_{m}$ Ratio}

Three weeks after transplanting, measurements of midday $\mathrm{F}_{\mathrm{v}} / \mathrm{F}_{\mathrm{m}}$ ratio were made with the Plant Efficiency Analyser, PEA, (Hansatech Instruments Ltd., England). All $\mathrm{F}_{\mathrm{v}} / \mathrm{F}_{\mathrm{m}}$ ratios were taken from the same leaves from which $A_{\text {sat }}$ and $g_{\text {ssat }}$ were recorded. The readings were carried out $1230 \mathrm{~h}$ to $1330 \mathrm{~h}$. Attached leaves were pre-darkened with clips for 15 min prior to measurements. Dark-adapted leaves were placed under the light pipe and irradiated with the pulsed lower intensity-measuring beam to measure $\mathrm{F}_{0}$, initial chlorophyll fluorescence. $\mathrm{F}_{\mathrm{m}}$, maximum chlorophyll fluorescence was assessed by $0.8 \mathrm{~s}$ of saturated pulse $\left(>6000 \mu \mathrm{mol} \cdot \mathrm{m}^{-2} \cdot \mathrm{s}^{-1}\right)$. The variable fluorescence yield, $\mathrm{F}_{\mathrm{v}}$, was determined by $\mathrm{F}_{\mathrm{m}}-\mathrm{F}_{0}$. The efficiency of excitation energy captured by open PSII reaction centres in dark-adapted plant samples was estimated by the fluorescence $F_{v} / F_{m}$ ratio.

\subsection{Measurements of Photochemical Quenching (qP), Non-Photochemical Quenching (qN) and Electron Transport Rate (ETR)}

Leaf discs ( $1 \mathrm{~cm}$ diameter) were punctured and placed on moist filter papers in Petri dishes. They were pre-darkened for $15 \mathrm{~min}$ prior to measurements. Via the Imaging-PAM Chl Fluorometer (Walz, Effeltrich, Germany), images of fluorescence emission were digitized within the camera and transmitted via a Firewire interface (400 megabits/s) (Firewire-1394, Austin, TX, USA) to a personal computer for storage and analysis. Measurements and calculations of $\mathrm{qP}, \mathrm{qN}$ and ETR were determined according to He et al. [17].

\subsection{Determination of Total Phenolic Compounds}

The concentration of total phenolic compounds was determined in methanol extracts using a colorimetric method [18] [19]. To extract the phenolic compounds, $0.5 \mathrm{~g}$ of fresh shoot tissues were grinded with liquid nitrogen and $5 \mathrm{ml}$ of $80 \%$ methanol. The extracts were shaken for $30 \mathrm{~min}$ at $2000 \mathrm{rpm}$ and centrifuged for $20 \mathrm{~min}$ at $3500 \mathrm{rpm}$. The supernatants were transferred to clean tubes. $0.5 \mathrm{ml}$ of extract was diluted with 0.5 $\mathrm{ml}$ of diluted Folin-Ciocalteau reagent and $1 \mathrm{ml}$ of $7.5 \% \mathrm{Na}_{2} \mathrm{CO}_{3}$ solution. After $20 \mathrm{~min}$, the absorbances were measured at $765 \mathrm{~nm}$ using UV-2550 spectrophotometer (Shimadzu, Japan). Total phenolic compounds of the samples were expressed as gallic acid equivalents in micrograms per gram of FW.

\subsection{Determination of Inorganic Dietary Minerals}

Dried shoot tissues of $0.2 \mathrm{~g}$ were microwave-digested in $4 \mathrm{ml}$ of $65 \% \mathrm{HNO}_{3}$ using UltraWAVE single reaction chamber microwave digestion system (Milestone, US). Di- 
gested samples were diluted with the addition of Milli-Q water to a total volume of 25 $\mathrm{ml}$. Inductively coupled plasma optical emission spectrophotometry (ICP-OES) was performed using Optima 8300 ICP-OES Spectrometer and WinLab 32 (Perkin Elmer, US). The data retrieved were then used to calculate the concentrations.

\subsection{Statistical Analysis}

Levene's test was used to ensure equal variances across samples of the four treatments. One-way analysis of variances (ANOVA) and Tukey's multiple comparison test were used to discriminate between means of the different treatments, where means with $p<$ 0.05 has significant differences. All statistical analyses were performed using MINITAB software (MINITAB Inc., US).

\section{Results}

\subsection{Shoot and Root Productivity}

Figure 1 shows $E$. sativa plants that were grown in a tropical greenhouse with aeroponic system at $20^{\circ} \mathrm{C}$-RZT (Figure $1(\mathrm{a})$ ) and other different RZTs for 4 weeks (Figure 1 (b)). Plants grown under ambient-RZT $\left(25^{\circ} \mathrm{C} / 38^{\circ} \mathrm{C}-\mathrm{RZT}\right)$ had the lowest shoot FW while those plants grown under $20^{\circ} \mathrm{C}$-RZT had highest productivity of shoot (Figure 2(a)). However, there were no significant differences in shoot FW implants grown at

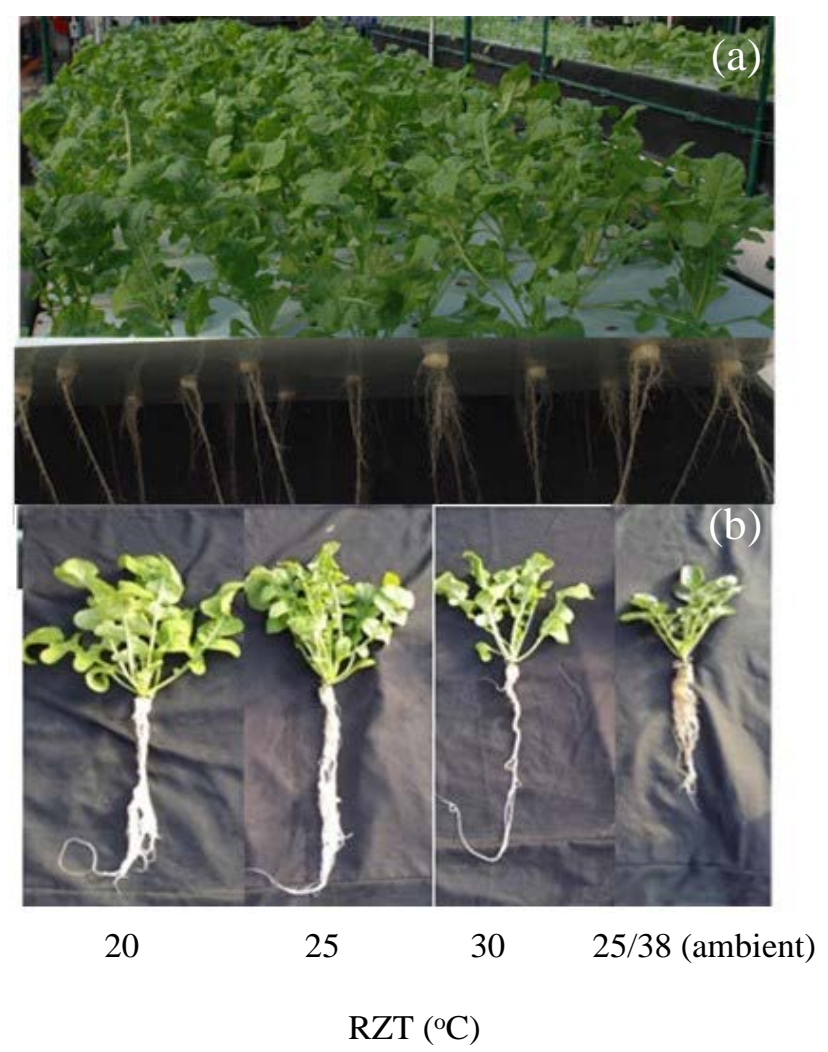

Figure 1. E. sativa plants grown in a tropical greenhouse with aeroponic system at $20^{\circ} \mathrm{C}-\mathrm{RZT}$ (a) and grown under different RZTs for 4 weeks (b). 

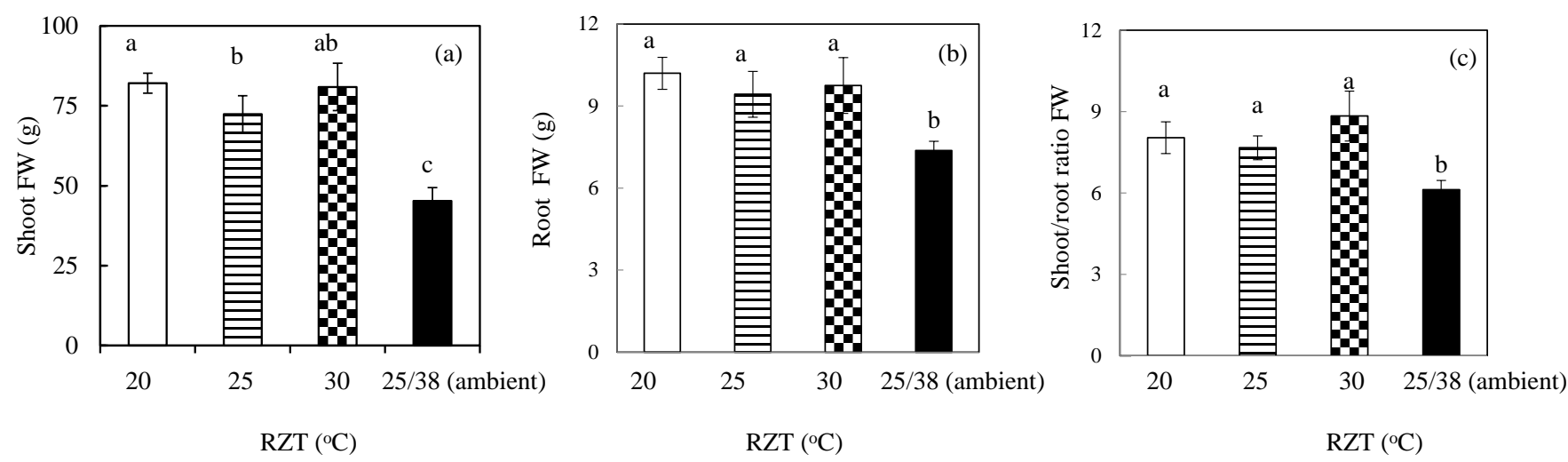

Figure 2. Shoot (a), root (b) FW and shoot/root ratio FW of E. sativa grown under different RZTs. Each bar represents the mean measurements from 5 plants $(n=5)$. Vertical bars represent standard errors. Means with the same alphabet above the bars are not statistically different $(p>0.05)$ as determined by Tukey's multiple comparison test.

$25^{\circ} \mathrm{C}$ - and $30^{\circ} \mathrm{C}-\mathrm{RZT}$. For root FW (Figure $2(\mathrm{~b})$ ) and shoot/root ratio FW (Figure $2(\mathrm{c})$ ), there were no significant differences among $E$. sativa grown under $20^{\circ} \mathrm{C}-, 25^{\circ} \mathrm{C}$ and $30^{\circ} \mathrm{C}$-RZT and they were significantly higher than plants grown at ambient-RZT.

\subsection{Photosynthetic Gas Exchanges at Different RZTs}

No significant differences in $A_{\text {sat }}$ (Figure 3(a)) and $g_{s \text { sat }}$ (Figure 3(b)) were observed among plants grown under $20^{\circ} \mathrm{C}-, 25^{\circ} \mathrm{C}$ - and $30^{\circ} \mathrm{C}$-RZTs. However, these two parameters were significantly higher than those of ambient-RZT plants $\left(25^{\circ} \mathrm{C} / 38^{\circ} \mathrm{C}-\mathrm{RZT}\right)$.

\subsection{Photosynthetic Utilization of Radiant Energy at Different RZTs}

$20^{\circ} \mathrm{C}$-RZT and A-RZT plants had the highest and lowest midday $\mathrm{F}_{\mathrm{v}} / \mathrm{F}_{\mathrm{m}}$ ratio respectively (Figure 4). High midday PPFD induced dynamic photo inactivation, indicated by $<0.8 \mathrm{~F}_{\mathrm{v}} / \mathrm{F}_{\mathrm{m}}$ ratios. Decreasing $\mathrm{F}_{\mathrm{v}} / \mathrm{F}_{\mathrm{m}}$ ratio was observed with increasing RZTs. In fact, $E$. sativa grown under $20^{\circ} \mathrm{C}$-RZT had very mild photo inhibition as midday Fv/Fm ratio was very close to 0.8 . Figure 5 shows the light response curves of ETR, $\mathrm{qP}$ and $\mathrm{qN}$ from E. sativa grown under different RZTs. For all plants, ETR increased with increasing PPFD from 15 to $715 \mu \mathrm{mol} \cdot \mathrm{m}^{-2} \cdot \mathrm{s}^{-1}$ and decreased with further increasing PPFD beyond $715 \mu \mathrm{mol} \cdot \mathrm{m}^{-2} \cdot \mathrm{s}^{-1}$ (Figures 5(a)-(d)). Although the light response curves were similar for all plants, at a PPFD of $605 \mu \mathrm{mol} \cdot \mathrm{m}^{-2} \cdot \mathrm{s}^{-1}$, which was close to their growth PPFD, the ETR values indicated by black arrows, for plants grown under $20^{\circ} \mathrm{C}-, 25^{\circ} \mathrm{C}$ - and $30^{\circ} \mathrm{C}$-RZT were similarly but significantly higher than those of plants grown under ambient-RZT. Although qP decreased and qN increased with increasing PPFDs from 15 to $1585 \mu \mathrm{mol} \cdot \mathrm{m}^{-2} \cdot \mathrm{s}^{-1}$ for all plants, under higher PPFDs, the values of $\mathrm{qP}$ and $\mathrm{qN}$ were similarly but significantly higher in plants grown at $20^{\circ} \mathrm{C}-, 25^{\circ} \mathrm{C}$ - and $30^{\circ} \mathrm{C}$-RZTs than at ambient-RZT. For instance, the average values of $\mathrm{qP}$ and $\mathrm{qN}$ measured at a PPFD of $605 \mu \mathrm{mol} \cdot \mathrm{m}^{-2} \cdot \mathrm{s}^{-1}$ (indicated by blank arrows), were 0.767 (Figure 5(e)), 0.782 (Figure 5(f)), 0.765 (Figure 5(g)), and 0.617 (Figure 5(h)), respectively for $20^{\circ} \mathrm{C}-, 25^{\circ} \mathrm{C}$ - and $30^{\circ} \mathrm{C}$ - and ambient-RZT. 

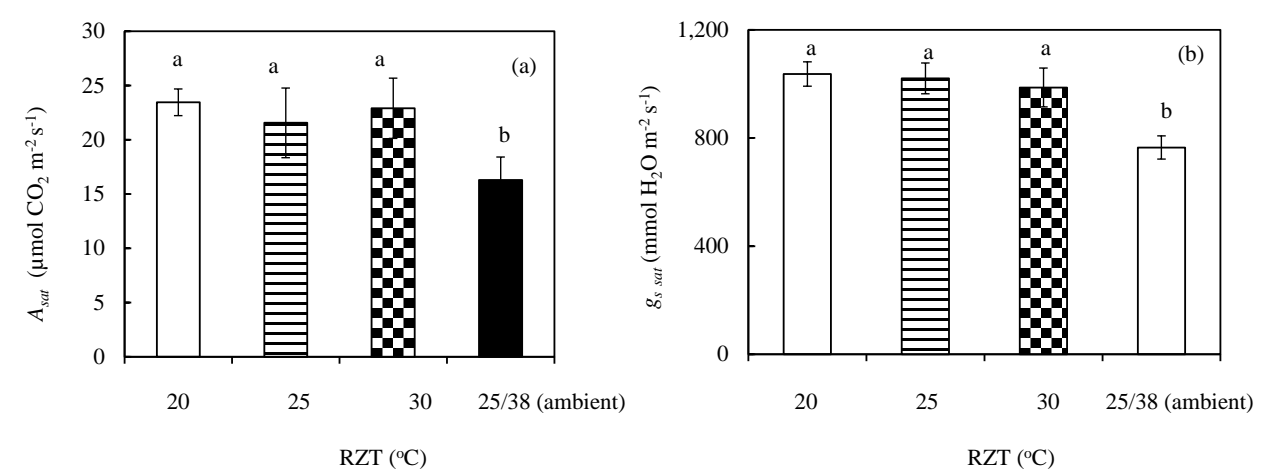

Figure 3. $A_{\text {sat }}$ (a) and $g_{\text {s sat }}(\mathrm{b})$, of $E$. sativa grown under different RZTs $(\mathrm{n}=4)$. Means with the same alphabet above the bars are not statistically different $(p>0.05)$ as determined by Tukey's multiple comparison test.

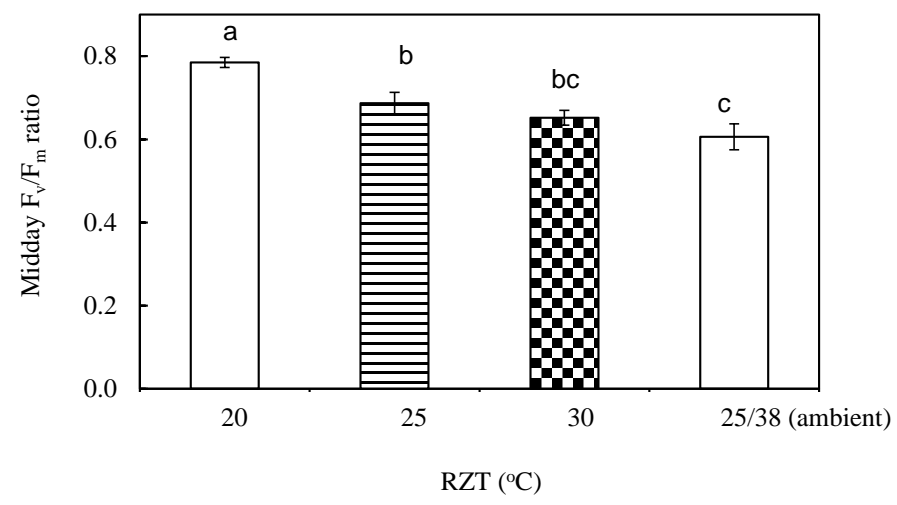

Figure 4. Midday $\mathrm{F}_{\mathrm{v}} / \mathrm{F}_{\mathrm{m}}$ ratio of $E$. sativa grown at different $\mathrm{RZTs}(\mathrm{n}=8)$. Means with the same alphabet above the bars are not statistically different $(p>0.05)$ as determined by Tukey's multiple comparison test.
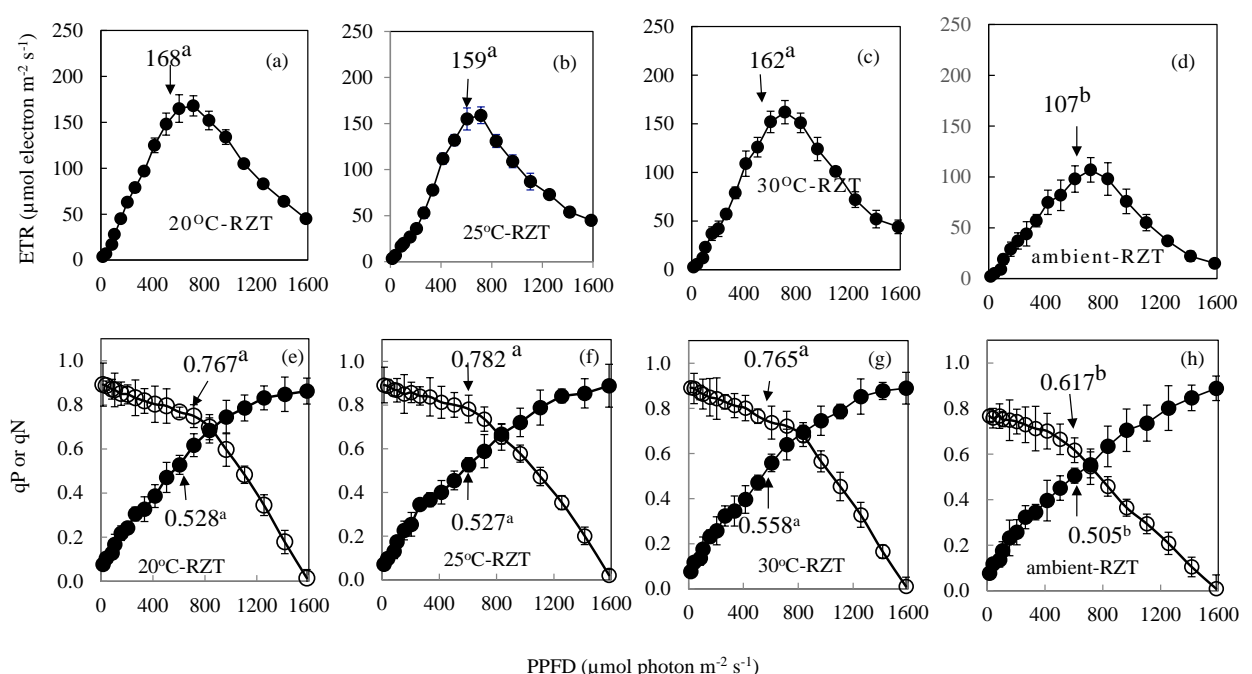

$\operatorname{PPFD}\left(\mu \mathrm{mol}\right.$ photon $\left.\mathrm{m}^{-2} \mathrm{~s}^{-1}\right)$

Figure 5. Light responses curves of $\operatorname{ETR}(a, b, c, d), q P$ (open circle) and qN (solid circle) (e, f, g, h) of E. sativa grown at different RZTs $(\mathrm{n}=15)$. Black arrows show the values measured at a PPFD of $605 \mu \mathrm{mol}$ photon $\left.\mathrm{m}^{-2} \cdot \mathrm{s}^{-1}\right)$. Means with the same alphabet above the bars are not statistically different $(p>0.05)$ as determined by Tukey's multiple comparison test. 


\subsection{Nutritional Qualities}

The content of total phenolic compounds was significantly higher in ambient-RZT plants as compared to plants of other RZTs, which had similar levels (Figure 6(a)). On the other hand, the contents of inorganic minerals such as $\mathrm{K}, \mathrm{Mg}$, $\mathrm{Ca}$ and $\mathrm{Fe}$ in E. sativa were different among the different RZT treatments. For example, $\mathrm{K}$ and $\mathrm{Ca}$ contents were highest in E. sativa grown at $20^{\circ} \mathrm{C}$-RZT followed by those grown under $25^{\circ} \mathrm{C}$ - and $30^{\circ} \mathrm{C}-\mathrm{RZT}$ and E. sativagrown at ambient-RZT had the lowest $\mathrm{K}$ and $\mathrm{Ca}$ contents (Figure $6(\mathrm{~b})$ and Figure $6(\mathrm{~d})$ ). For $\mathrm{Mg}$, E. sativa grown under $20^{\circ} \mathrm{C}-, 25^{\circ} \mathrm{C}$ - and $30^{\circ} \mathrm{C}-\mathrm{RZT}$ had similar higher content than that of ambient-RZT plants (Figure 6(c)). E. sativa grown at $30^{\circ} \mathrm{C}$-RZT had the highest $\mathrm{Fe}$ content followed by those grown under $20^{\circ} \mathrm{C}$ - and $25^{\circ} \mathrm{C}-\mathrm{RZT}$ whereas plants grown under ambient-RZT had the lower Fe content.

\section{Discussion}

In the present study, the biomass of both shoot and root of $E$. sativa were significantly higher at $20^{\circ} \mathrm{C}$-RZT compared to those grown at ambient-RZT (Figure 1(b) and Figure 2). The lowest shoot and root FW and shoot/root ratio FW observed in E. sativa grown under high ambient-RZTimply that high RZT affected not only the productivity of $E$. sativa grown in the tropical greenhouse but also photoassimilate partitioning between shoot and root. E. sativa grown under high RZT with more photoassimilates partitioned to roots than shoot (Figure 1 (c)) and this has been previously reported by our team in lettuce [5] [6] and other researchers in other plant species [20] [21]. However, similar to temperate lettuce, cooling the RZ of E. sativa could alleviate such adversely effects on productivity [5] [6] [22]. Our ${ }^{14} \mathrm{C}$ feeding experiments suggested that the younger developing leaves of lettuce grown under cooling-RZT had greater sink strength [6]. It was interesting to note that there were no significant differences in root $\mathrm{FW}$ and shoot/root ratio $\mathrm{FW}$ among E. sativa grown under $20^{\circ} \mathrm{C}-, 25^{\circ} \mathrm{C}$ - and $30^{\circ} \mathrm{C}$ RZT, indicating that the optimal cool-RZT for E. sativa was much broader that the temperate lettuce that had a narrow optimal cool-RZT at about $20^{\circ} \mathrm{C}$ [10] [11]. Mature
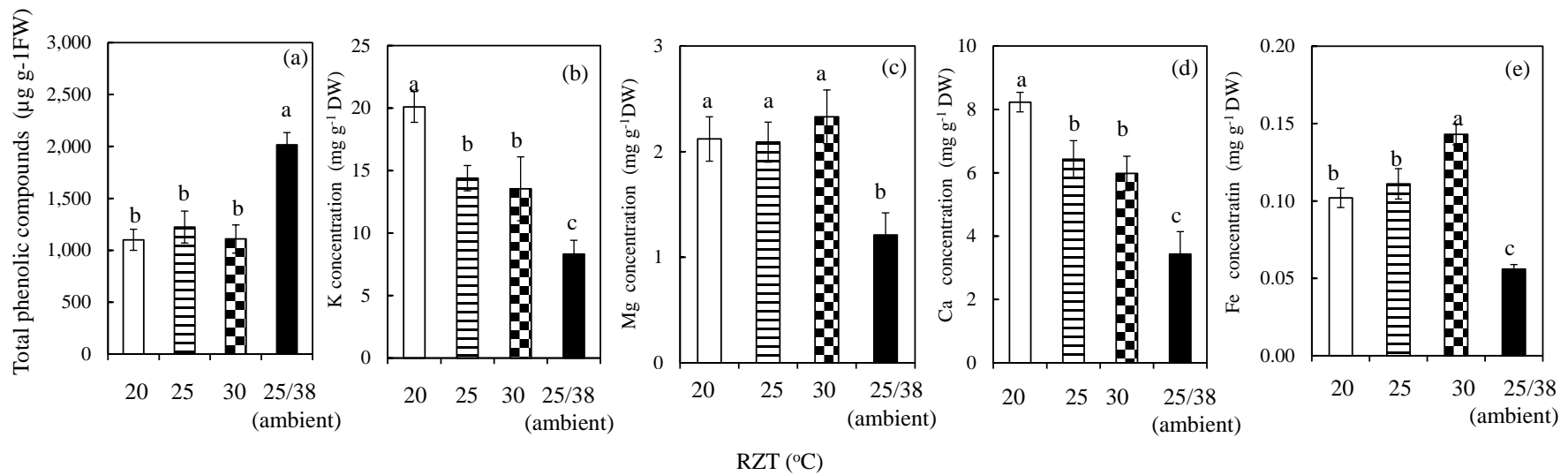

Figure 6. Total phenolic compound (a), ptassium, K (b), calcium, Ca (c), magnesium, $\mathrm{Mg}$ (d) and iron, Fe (e) concentrations of E. sativa grown at different RZTs $(n=4)$. Means with the same alphabet above the bars are not statistically different $(p>0.05)$ as determined by Tukey's multiple comparison test. 
E. sativa plants (4 weeks after transplanting, Figure 1) showed that ambient-RZT plants had much smaller root system with shortest root length but thick root diameter (data not shown) compared to that of E. sativa grown under other cooler RZT. These concur with the discussion of our various studies where inhibitory effects on root elongation and lateral growth but promoting root thickening were observed in plants grown at high RZTs [5]-[7] [23]. The root thickening may be due to the synthesis of chemical signals such as ethylene [8] [24], that was further confirmed by our team recently [25]. Effects of RZTs on ethylene production and root chickening of $E$. sativa merits our future study.

Contrary to our previous studies on lettuce [10] [11] [14], RZT did not seem to have significant impact on photosynthesis of $E$. sativa from $20^{\circ} \mathrm{C}$ to $30^{\circ} \mathrm{C}$ although their $A_{\text {sat }}$ (Figure 3(a)) and $g_{s \text { sat }}$ (Figure 3(b)) were significantly lower under hot ambient-RZT. $A_{\text {sat }}$ of $E$. sativa grown under different RZTs correlate well with $g_{s}$ sat. Lower $g_{s}$ sat indicated stomatal closure or partially closure when roots were subjected to high RZTs [12] [14]. Stomatal closure could deplete $\mathrm{CO}_{2}$ in the intercellular spaces and at the chloroplast level, thus reducing Asat [26] and this is termed a stomatal limitation of photosynthesis [12] [14] that occurred in E. sativa grown under ambient-RZT. High RZT resulted in stomatal limitation of photosynthesis was also reported in the studies of tomatoin a greenhouse [27]. Tomato plants that were grown at similar shoot temperature of $25^{\circ} \mathrm{C}$ but 5 different RZTs of $12^{\circ} \mathrm{C}, 18^{\circ} \mathrm{C}, 24^{\circ} \mathrm{C}, 30^{\circ} \mathrm{C}$ and $36^{\circ} \mathrm{C}$ showed that photosynthetic $\mathrm{CO}_{2}$ uptake, was the highest at $24^{\circ} \mathrm{C}-\mathrm{RZT}$ but the lowest at $36^{\circ} \mathrm{C}-\mathrm{RZT}$ [27]. We have also reported that temperate lettuce exposed to high solar irradiation (maximum PPFD circa $1800 \mu \mathrm{mol} \cdot \mathrm{m}^{-2} \cdot \mathrm{s}^{-1}$ ) in the tropical greenhouse accompanied by high RZT experienced not only stomatal but also non-stomatal limitations of photosynthesis supported by decreases of leaf Chl content and $\mathrm{Chl}$ fluorescence $\mathrm{F}_{\mathrm{v}} / \mathrm{F}_{\mathrm{m}}$, ratio [12]. In the present study, average midday fluorescence $\mathrm{F}_{\mathrm{v}} / \mathrm{F}_{\mathrm{m}}$, ratios were $0.785,0.678,0.652$ and 0.606 , respectively measured from E. sativa grown under $20^{\circ} \mathrm{C}$-, $25^{\circ} \mathrm{C}$-, $30^{\circ} \mathrm{C}$ - and ambient-RZT (Figure 4). These results indicated that dynamicPSII photo inhibition was rather mild or moderate and was not accompanied by decreases of predawn $\mathrm{F}_{\mathrm{v}} / \mathrm{F}_{\mathrm{m}}$, ratio and leaf Chl content (data not shown). These could be due to the lower solar irradiation inside the greenhouse (maximum PPFD circa $600 \mu \mathrm{mol} \cdot \mathrm{m}^{-2} \cdot \mathrm{s}^{-1}$ ) in the present study compared to our previous experiment with lettuce discussed earlier [12]. However, there was still a significant lower midday $\mathrm{F}_{\mathrm{v}} / \mathrm{F}_{\mathrm{m}}$, ratio in $E$. sativa grown under ambient-RZT compared to those grown under cooler RZT (Figure 4). It well known that photo inhibition could occur at low and moderate light when other adverse conditions such as super- or sub-optimal temperature were present [28]. At optimal growing temperature and low light, the electron flow from PSII does not exceed the capacity of PSI electron acceptors to cope with electrons, and PSI remains stable [29]-[31]. Recently, it has been reported that PS II photo inhibition was regarded as an ultimate mechanism for protecting PSI activity [31]. In the present study, lower ETR (Figure 5(d)) and qP (Figure (5h)) in E. sativa grown under ambient-RZT compared to other cooler RZT (Figures 5(a)-(c) and Figures 5(e)-(g)) seemed to supported this conclusion. Non- 
photochemical quenching ( $\mathrm{qN}$ or NPQ) help to regulate and protect photosynthesis in environments in which light energy absorption exceeds the capacity for light utilization and thus, avoid over reduction and potential damage to PS II [32] [33]. However, instead of higher qN, lower qN was observed in E. sativa grown under ambient- RZT (Figure 5(h)). High levels of qN were typically associated with higher level of carotenoids [34] [35]. However, in the present study, levels of carotenoids varied little among the different RZT treatment (data not shown).

Plant phenolic compounds of plants are essential human diet, and are of considerable interest due to their antioxidant properties [36]. It has been reported that low growth temperature decreased the content of some phenolic compounds in pea (Pisum sativum L.) seedlings [37]. In the present study, while plants grown under other cooler RZTs had low total phenolic content, plants grown under ambient-RZT had the highest total phenolic content (Figure 6(a)). Bita and Gerats reported that heat stress led to the production of reactive oxygen species (ROS). Anti-oxidants such as phenolics compounds are produced by plants in order to resist oxidative stress [38]. Results from this study thus indicate that phenolic compounds may produce to counter the oxidative stress at ambient-RZT. At other RZTs, the cooler RZTs had alleviated the oxidative effects of heat stress.

RZT affects the root morphology and productivity of E. sativa. Would RZT also affects the dietary mineral uptake of $E$. sativa since high RZT results in poor root development, reductions of uptake and transport of mineral and inhibition of nitrogen metabolism [14] [39]? Compared to plants grown at cooler RZT, ambient-RZT plants had lower shoot K (Figure 6(b)), Mg (Figure 6(c)), Ca (Figure 6(d)) and Fe (Figure 6(e)) concentration. When comparisons made among $20^{\circ} \mathrm{C}-, 25^{\circ} \mathrm{C}$ - and $30^{\circ} \mathrm{C}-\mathrm{RZT}, 20^{\circ} \mathrm{C}$ $\mathrm{ZT}$ plants had higher $\mathrm{K}$ and $\mathrm{Ca}$ concentration, indicating that the roots of $E$. sativa need much cooler temperature to absorb and translocate these two elements to the shoot, resulting from well-established root systems under cool-RZTs [5] [7]. For Mg, there were no significant differences among the plants grown under three cool-RZTs. It was surprise to note that Fe concentration was the highest in plants grown under $30^{\circ} \mathrm{C}$ RZT. Based on the above results, a general trend was observed, where increase in RZTs generally led to increase in total phenolic content and decrease in mineral content. These hinted a possible manipulation of organic and mineral nutrient quality and productivity in E. sativa using different RZTs.

\section{Conclusion}

In conclusion, the growth of $E$. sativa plants was adversely affected by hot ambient-RZT in a tropical greenhouse. Ambient-RZT led to heat stress effects on E. sativa, such as poor growth, midday photo inhibition, stomotal limitation of photosynthesis and generally low mineral concentrations. $20^{\circ} \mathrm{C}$-RZT would be a suitable RZT for the cultivation of $E$. sativa, as plants had enhanced productivity, mild midday photoinhibition, high photosynthetic ate and generally high mineral concentrations. However, plants growing at $20^{\circ} \mathrm{C}$-RZT have low antioxidants such as total phenolic compounds. As this 
is a preliminary study to provide a potential method of cultivating $E$. sativa in the tropics, more studies should be carried out to manipulate the nutritional values by adjusting other factors such as light or $\mathrm{CO}_{2}$ levels.

\section{Acknowledgements}

This project was funded by Singapore Millennium Foundation, Singapore and teaching materials' vote of National Institute of Education, Nanyang Technological University, Singapore.

\section{References}

[1] Algasoumi, S., Al-Sohaibani, M., Al-Howiriny, T., Al-Yahya, M. and Rafatullah, S. (2009) Rocket "Eruca sativa": AAalad Herb with Potential Gastric Anti-Ulcer Activity. World Journal of Gastroenterology, 15, 1958-1965. http://dx.doi.org/10.3748/wjg.15.1958

[2] Emtenan, M.H., Eman, M.H., Rowida, M.R. and Amer, H.A. (2010) Bio-Protective Effects of Eruca sativaseed Oil against the Hazardous Effect of Aflatoxin B1 in Male Rabbits. International Journal of Academic Research, 2, 67-74.

[3] Maia, M.L., Correia-Sá, L., Coelho, A., Barroso, M.F., Dominguea, V.F. and Delerue-Matos, C. (2015) Eruca sativa: Benefits as Antioxidants Aource versus Risks of Already Banned Pesticides. Journal of Environmental Science and Health, Part B, 50, 338-345. http://dx.doi.org/10.1080/03601234.2015.1000178

[4] Dolezaloval, I., Duchoslav, M. and Dusek, K. (2013) Biology and Yield of Rocket (Eruca sativa Mill.) under Field Conditions of the Czech Republic (Central Europe). Notulae Botanicae Horti Agrobotanici Cluj-Napoca, 41, 530-537.

[5] Tan, L.P., He, J. and Lee, S.K. (2002) Effects of Root-Zone Temperature on the Root Development and Nutrient Uptake of Lactuca sativa L. cv 'Panama' Frown in an Aeroponic System in the Tropics. Journal of Plant Nutrition, 25, 297-314. http://dx.doi.org/10.1081/PLN-100108837

[6] He, J., Tan, L.P. and Lee, S.K. (2009) Root-zone Temperature Effects on Photosynthesis, ${ }^{14} \mathrm{C}$-Photoassimilate Partitioning and Growth of Temperate Lettuce (Lactuca sativa cv. "Panama”) Grown in the Tropics. Photosynthetica, 47, 95-103.

http://dx.doi.org/10.1007/s11099-009-0015-6

[7] He, J. (2010) Mineral Nutrition of Aeroponically Grown Subtropical and Temperate Crops in the Tropics with Manipulation of Root-Zone Temperature at Different Growth Irradiances. Plant Stress, 4, 14-30.

http://www.globalsciencebooks.info/Online/GSBOnline/images/2010/PS 4(SI2)/PS 4(SI2)1 4-30o.pdf

[8] Qin, L., He, J., Lee, S.K. and Dodd, I.C. (2007) An Assessment of Ethylene Mediation of Lettuce (Lactuca sativa) Root Growth at High Temperatures. Journal of Experimental Botany, 58, 3017-3024. http://dx.doi.org/10.1093/jxb/erm156

[9] He, J., Chua, N.Y.A. and Qin, L. (2008) Interaction between Iron Stress and Root-Zone Temperature on Physiological Aspects of Aeroponically Grown Chinese Broccoli (Brassica alboglabra). Journal of Plant Nutrition, 31, 1-20.

[10] He, J. and Lee, S.K. (1998) Growth and Photosynthetic Responses of Three Aeroponically Grown Lettuce Cultivars (Lactuca sativa L.) to Different Rootzone Temperatures and Growth Irradiances under Tropical Aerial Condition. The Journal of Horticultural Science and Biotechnology, 73, 173-180. http://dx.doi.org/10.1080/14620316.1998.11510961 
[11] He, J. and Lee, S.K. (1998) Growth and Photosynthetic Characteristics of Lettuce (Lactuca sativa L.) Grown under Fluctuating Hot Ambient Temperatures with the Manipulation of Cool Rootzone Temperature. Journal of Plant Physiology, 152, 387-391. http://dx.doi.org/10.1016/S0176-1617(98)80252-6

[12] He, J., Lee, S.K. and Dodd, I.C. (2001) Limitations to Photosynthesis of Lettuce Grown under Tropical Conditions: Alleviation by Root-Zone Cooling. Journal of Experimental Botany, 52, 1323-1330. http://dx.doi.org/10.1093/jexbot/52.359.1323

[13] He, J. and Lee, S.K. (2004) Photosynthetic Utilization of Radiant Energy by Temperate Lettuce Grown under Natural Tropical Condition with Manipulation of Root-Zone Temperature. Photosynthetica, 42, 457-463. http://dx.doi.org/10.1023/B:PHOT.0000046166.29815.94

[14] He, J. (2009) Impact of Root-Zone Temperature on Photosynthetic Efficiency of Aeroponically Grown Temperate and Subtropical Vegetable Crops in the Tropics. In: Buchner, Th.B. and Ewingen, NH., Eds., Theory and Applications in Energy, Biotechnology and Nanotechnology, Nova Science Publishers Inc., New York, Chapter 4, 111-143. http://trove.nla.gov.au/work/27991465?versionId=45343866

[15] Berry, A.B. (1975) Adaptation of Photosynthetic Processes to Stress. Science, 188, 644-650. http://dx.doi.org/10.1126/science.188.4188.644

[16] Vollenweider, P. and Gunthardt-Goerg, M.S. (2006) Diagnosis of Abiotic and Biotic Stress Factors Using Visible Symptoms in Foliage. Environmental Pollution, 140, 562-571. http://dx.doi.org/10.1016/j.envpol.2006.01.002

[17] He, J., Tan, B.H.G. and Qin, L. (2011) Source-to-Sink Relationship between Green Leaves and Green Pseudobulbs of $\mathrm{C}_{3}$ Orchid in Regulation of Photosynthesis. Photosynthetica, 49, 209-218. http://dx.doi.org/10.1007/s11099-011-0023-1

[18] Kan, H.-M. and Saltveit, M.E. (2002) Antioxidant Capacity of Lettuce Leaf Tissue Increases after Wounding. Journal of Agricultural and Food Chemistry, 50, 7536-7541. http://dx.doi.org/10.1021/jf020721c

[19] Ragee, S., Abdel-Aal, E.M. and Noaman, M. (2006) Antioxidant Activity and Nutrient Composition of Selected Cereals for Food Use. Food Chemistry, 98, 32-38. http://dx.doi.org/10.1016/j.foodchem.2005.04.039

[20] Sattelmacher, B., Marschner, H. and Kühne, R. (1990) Effects of the Temperature of the Rooting Zone on the Growth and Development of Roots of Potato (Solanum tuberosum). Annals Botany, 65, 27-36.

[21] Pardales Jr., J.R., Yamauchi, A. and Kono, Y. (1991) Growth and Development of Sorghum Roots after Exposure to Different Periods of a Hot Root-Zone Temperature. Environmental and Experimental Botany, 31, 397-403. http://dx.doi.org/10.1016/0098-8472(91)90037-O

[22] Luo, H.Y., He, J. and Lee, S.K. (2012) Interaction between Potassium Concentration and Root-Zone Temperature on Growth and Photosynthesis of Temperate Lettuce Grown in the Tropics. Journal of Plant Nutrition, 35, 1004-1021. http://dx.doi.org/10.1080/01904167.2012.671404

[23] He, J. (2016) Root Growth, Morphological and Physiological Characteristics of Subtropical and Temperate Vegetable Crops Grown in the Tropics under Different Root-Zone Temperature. In: Rigobelo, E.C., Ed., Plant Growth, In Press.

[24] Arshad, M. and Frakenberger Jr., W.T. (2002) Ethylene: Agricultural Sources and Applications. Kluwer Academic/Plenum Publishers, New York, 155-156. http://dx.doi.org/10.1093/aob/mcf201

[25] Choong, T.W., He, J., Lee, S.K. and Dodd, I. (2016) Growing Lactuca in an Aeroponic Sys- 
tem within a Tropical Greenhouse-Lower Accumulated Root Zone Ethylene Concentrations Corresponded with Higher Shoot Growth at Cooler Rootzone Temperatures. Frontierin Plant Science, In Press.

[26] Wong, S.C., Cowan, I.R. and Farquhar, G.D. (1985) Leaf Conductance in Relation to Rate of $\mathrm{CO}_{2}$ Assimilation. III. Influences of Water Stress and Photoinhibition. Plant Physiology, 78, 830-834. http://dx.doi.org/10.1104/pp.78.4.830

[27] Gosselin, A. and Trudel, M.J. (1984) Interaction between Root-Zone Temperature and Light Levels on Growth, Development and Photosynthesis of Lycopersicon esculentum Mill. Cultivar "Vendor". Scientia Horticulturae, 23, 313-321. http://dx.doi.org/10.1016/0304-4238(84)90027-X

[28] Guidi, L. and Degl'Innocenti, E. (2011) Imaging of Chlorophyll a Fluorescence: A Tool to Study Abiotic Stress in Plants. In: Shanker, A. and Venkateswarlu, B., Eds., Abiotic Stress in Plants-Mechanisms and Adaptations, InTech, West Palm Beach. http://dx.doi.org/10.5772/22281

[29] Munekage, Y., Hojo, M., Meurer, J., Endo, T., Tasaka, M. and Shikanai, T. (2002) PGR5 Is Involved in Cyclic Electron Flow around Photosystem I and Is Essential for Photoprotection in Arabidopsis. Cell, 110, 361-371. http://dx.doi.org/10.1016/S0092-8674(02)00867-X

[30] Tikkanen, M., Grieco, M., Kangasjarvim, S. and Aro, E.M. (2010) Thylakoid Protein Phosphorylation in Higher Plant Chloroplasts Optimizes Electron Transfer under Fluctuating Light. Plant Physiology, 152, 723-735. http://dx.doi.org/10.1104/pp.109.150250

[31] Tikkanen, M. and Aro, E.M. (2014) Integrative Regulatory Network of Plant Thylakoid Energy Transduction. Trends in Plant Science, 19, 10-17.

http://dx.doi.org/10.1016/j.tplants.2013.09.003

[32] Baker, N.R. (1991) A Possible Role for Photosystem II in Environmental Perturbations of Photosynthesis. Physiologia Plantarum, 81, 563-570.

http://dx.doi.org/10.1111/j.1399-3054.1991.tb05101.x

[33] Müller, P., Li, X.P. and Niyogi, K.K. (2001) Non-Photochemical Quenching. A Response to Excess Light Energy. Plant Physiology, 125, 1558-1566.

[34] Demmig-Adams, B. (1990) Carotenoids and Photoprotection in Plants: A Role for the Xanthophyll Zeaxanthin. Biochimica et Biophysica Acta (BBA)-Bioenergetics, 1020, 1-24. http://dx.doi.org/10.1016/0005-2728(90)90088-L

[35] Dreuw, A., Fleming, G.R. and Head-Gordon, M. (2005) Role of Electron-Transfer Quenching of Chlorophyll Fluorescence by Carotenoids in Non-Photochemical Quenching of Green Plants. Biochemical Society Transactions, 33, 858-862. http://dx.doi.org/10.1042/BST0330858

[36] Balasundram, N., Sundram, K. and Samman, S. (2006) Phenolic Compounds in Plants and Agri-Industrial By-Products: Antioxidant Activity, Occurrence, and Potential Uses. Food Chemistry, 99, 191-203. http://dx.doi.org/10.1016/j.foodchem.2005.07.042

[37] Rudikovskaya, E.G., Fedorova, G.A., Dudareva, L.V., et al. (2008) Effect of Growth Temperature on the Composition of Phenols in Pea Roots. Russian Journal of Plant Physiology, 55,712 .

[38] Bita, C.E. and Gerats, T. (2013) Plant Tolerance to High Temperature in a Changing Environment: Scientific Fundamentals and Production of Heat Stress-Tolerant Crops. Frontier in Plant Science, 4, 273. http://dx.doi.org/10.3389/fpls.2013.00273

[39] Malamy, J.E. (2005) Intrinsic and Environmental Response Pathways That Regulate Root System Architecture. Plant Cell, \& Environment, 28, 67-77. http://dx.doi.org/10.1111/j.1365-3040.2005.01306.x 
Submit or recommend next manuscript to SCIRP and we will provide best service for you:

Accepting pre-submission inquiries through Email, Facebook, LinkedIn, Twitter, etc.

A wide selection of journals (inclusive of 9 subjects, more than 200 journals)

Providing 24-hour high-quality service

User-friendly online submission system

Fair and swift peer-review system

Efficient typesetting and proofreading procedure

Display of the result of downloads and visits, as well as the number of cited articles

Maximum dissemination of your research work

Submit your manuscript at: http://papersubmission.scirp.org/

Or contact ajps@scirp.org 